\title{
The Regulation of Glutamine Transport and Glutamine Synthetase in Salmonella typhimurium
}

\author{
By P. R. BETTERIDGE AND P. D. AYLING \\ Unit of Genetics, Department of Plant Biology, \\ The University, Hull HU6 ${ }_{7} R X$
}

(Received 30 December 1975)

\begin{abstract}
SUMMARY
Transport of glutamine by the high-affinity transport system is regulated by the nitrogen status of the medium. With high concentrations of ammonia, transport is repressed; whereas with Casamino acids, transport is elevated, showing behaviour similar to glutamine synthetase. A glutamine auxotroph, lacking glutamine synthetase activity, had elevated transport activity even in the presence of high concentrations of ammonia (and glutamine). This suggests that glutamine synthetase is involved in the regulation of the transport system. A mutant with low glutamate synthase activity had low glutamine transport and glutamine synthetase activities, which could not be derepressed. A mutant in the highaffinity glutamine transport system showed normal regulation of glutamate synthase and glutamine synthetase. Possible mechanisms for this regulation are discussed.
\end{abstract}

\section{INTRODUCTION}

Glutamine is an important intermediate in the assimilation of nitrogen. Its amide group can be used in the synthesis of several other amino acids and nitrogen-containing compounds (Meister, 1962). In addition, glutamine has been implicated in the formation of glutamate in nitrogen-limited cultures by the enzymes glutamine synthetase (reaction I) and glutamate synthase (reaction 2) in Klebsiella aerogenes and other Gram-negative bacteria (Tempest, Meers \& Brown, 1973), and in Escherichia coli (Miller \& Stadtman, 1972):

$$
\begin{aligned}
\mathrm{NH}_{3}+\text { Glutamate }+\mathrm{ATP} & \rightarrow \text { Glutamine }+\mathrm{ADP}+\mathrm{P}_{\mathrm{i}} \\
\text { Glutamine }+\alpha-\mathrm{Ketoglutarate}+\mathrm{NADPH}_{2} & \rightarrow 2 \text { Glutamate }+\mathrm{NADP} \\
\mathrm{NH}_{3}+\alpha-\text { Ketoglutarate }+\mathrm{NADPH}_{2} & \rightarrow \text { Glutamate }+\mathrm{NADP}+\mathrm{H}_{2} \mathrm{O}
\end{aligned}
$$

When ammonia is in excess, glutamate is formed by glutamate dehydrogenase (reaction 3 ). Recently Senior (1975), in studies on glutamate-nitrogen-limited chemostat cultures, has cast doubts on the importance of glutamate synthase in $E$. coli. However, he confirms the importance of glutamine synthetase under these conditions.

Because of the importance of glutamine in nitrogen metabolism, much attention has been paid to the regulation of glutamine synthetase. An elaborate system of controls has been elucidated, involving repression, feedback inhibition and covalent modification by adenylylation via a cascade system (for a review of these and other types of regulation, see Stadtman \& Ginsburg, 1974). Glutamine synthetase is also thought to be involved in Klebsiella in the regulation of several other systems in nitrogen metabolism, particularly histidase and proline oxidase (Prival, Brenchley \& Magasanik, 1973; Brenchley, Prival \& Magasanik, 1973).

We have studied the transport of glutamine from the medium into Salmonella typhimurium, 
Table I. Bacterial strains and their derivations

\begin{tabular}{|c|c|c|}
\hline Strain & Genotype* & Source \\
\hline $\begin{array}{l}\text { HUI } 88 \\
\text { HUI } 90\end{array}$ & $\left.\begin{array}{l}g \ln P 252 \\
\ln P^{+}\end{array}\right\}$ & Betteridge \& Ayling, I 975 \\
\hline $\begin{array}{l}\text { HU357 } \\
\text { HU358 } \\
\text { HU359 }\end{array}$ & $\begin{array}{l}\text { galE } \\
\text { galE gln-Io } \\
\text { galE Asm- }\end{array}$ & J. E. Brenchley \\
\hline HU36o & galE $\operatorname{gln}-10^{+}$ & HU358, transduction \\
\hline HU37I & hisF $6645 g \ln -52$ & S. G. Kustu \\
\hline
\end{tabular}

since this system may be considered as another process involved in nitrogen metabolism. It is known that glutamine is transported by two systems: the high-affinity $\left(g \ln P^{+}\right)$system and a low-affinity system (Ayling \& Betteridge, 1975). The low-affinity system is present in a $g \ln P^{-}$mutant lacking the high-affinity system (Betteridge \& Ayling, 1975; Ayling \& Betteridge, 1975). This study investigates the regulation of glutamine transport and, in particular, its relationship with the enzymes of glutamate and glutamine metabolism, especially glutamine synthetase. A preliminary report has been published (Betteridge \& Ayling, 1976).

\section{METHODS}

Bacteria. The strains of Salmonella typhimurium LT2 used in this work and their derivations are given in Table $\mathrm{I}$.

Media. Nutrient agar was obtained from Oxoid. Basal medium contained $\left(\mathrm{gl}^{-1}\right): \mathrm{K}_{2} \mathrm{HPO}_{4}$, 10.5; $\mathrm{KH}_{2} \mathrm{PO}_{4}, 4.5$; trisodium citrate. $2 \mathrm{H}_{2} \mathrm{O}, 0.47$; and $\mathrm{MgSO}_{4} \cdot 7 \mathrm{H}_{2} \mathrm{O}$, 0.05. Limitingnitrogen medium was basal medium supplemented with $\left(\mathrm{g}^{-1}\right)$ : D-glucose, 4 ; and Difco Casamino acids, I (except for derepression experiments, $0 \cdot 3$ ). Excess-nitrogen medium was limiting-nitrogen medium with $40 \mathrm{mM}-\left(\mathrm{NH}_{4}\right)_{2} \mathrm{SO}_{4}$. Chloramphenicol medium was basal medium with chloramphenicol (200 $\mu \mathrm{g} \mathrm{ml}^{-1}$; Chloromycetin, the kind gift of Parke-Davis).

Solutions of glutamine were freshly prepared and sterilized by filtration. Nutrient agar for the glutamine auxotrophs was supplemented with glutamine $\left(200 \mu \mathrm{g} \mathrm{ml}^{-1}\right)$. Where noted, glutamine was added to other media to give a final concentration of $2 \mathrm{mg} \mathrm{ml}^{-1}$.

Chemicals. These were as described by Betteridge \& Ayling (1975). In addition, L-glutamine (grade III), nicotinamide adenine dinucleotide phosphate reduced form (NADPH), adenosine diphosphate (ADP) and $\alpha$-ketoglutarate were obtained from Sigma; imidazole and 2-methylimidazole were from Koch-Light; and 2,4-dimethylimidazole was from Gallard-Schlesinger, Carle Place, New York. L-[U-14 $\left.{ }^{14}\right]$ Glutamine $\left(49 \mu \mathrm{Ci} \mu \mathrm{mol}^{-1}\right)$ was from The Radiochemical Centre, Amersham, Buckinghamshire.

Growth conditions. All cultures were grown with shaking at $37^{\circ} \mathrm{C}$ and were harvested by centrifuging.

Growth of bacteria for transport and enzyme assays. A culture was incubated overnight in Io $\mathrm{ml}$ excess-nitrogen medium, harvested, resuspended in an equal volume of basal medium, and diluted $\mathrm{I}$ in 200 into either limiting- or excess-nitrogen medium. This culture was grown until it had an extinction $\left(E_{650}\right)$ of 0.6 to 0.8 . (An extinction of $\mathrm{I} \cdot 0$ corresponded to $0.46 \mathrm{mg}$ dry wt $\mathrm{ml}^{-1}$.) For transport assays, $\mathrm{IO} \mathrm{ml}$ portions were harvested, washed once in an equal volume of cold $\left(6^{\circ} \mathrm{C}\right)$ chloramphenicol medium, and resuspended in $2 \mathrm{ml}$ cold chloramphenicol medium. Cultures for the enzyme assays ( $190 \mathrm{ml})$ were harvested, washed 
once in an equal volume of Tris buffer $\mathrm{pH} 8.0$ containing ro mM-magnesium chloride, and the pellet was frozen and stored at $-20^{\circ} \mathrm{C}$.

Growth of bacteria for derepression experiments. A culture was incubated overnight in $40 \mathrm{ml}$ excess-nitrogen medium, then diluted into $200 \mathrm{ml}$ of the same medium and grown for $75 \mathrm{~min}$. At this time, when the culture was growing exponentially, three different samples were taken: a $10 \mathrm{ml}$ sample for the transport assay; an $80 \mathrm{ml}$ sample for the enzyme assay; and an $80 \mathrm{ml}$ sample to provide the inoculum for the derepression experiment. All three samples were harvested together. The first two were harvested and washed as previously described. The third sample was harvested, washed once with an equal volume of basal medium at room temperature and resuspended in $10 \mathrm{ml}$ basal medium at $37^{\circ} \mathrm{C}$. Portions $(5 \mathrm{ml})$ were then added to either limiting- or excess-nitrogen medium $(200 \mathrm{ml})$ at $37^{\circ} \mathrm{C}$ and incubated. The start of incubation was taken as zero time for the derepression experiment, and was $30 \mathrm{~min}$ after the time at which the three samples were originally taken. At 60 and $90 \mathrm{~min}$ after this zero time, samples were removed and prepared for transport and enzyme assays as described above.

Transport assays. During preliminary experiments it was found that in cultures harvested and stored in the presence of glucose, transport activity declined by $42 \%$ in $\mathrm{I} \mathrm{h}$. But when cultures were harvested without glucose and stored at $6{ }^{\circ} \mathrm{C}$ as described above, transport activity was stable for at least $90 \mathrm{~min}$ after the end of harvesting: thus this procedure was used in all experiments, and transport assays were completed within $90 \mathrm{~min}$. The washed bacterial suspensions were adjusted to $100 \mu \mathrm{g}$ dry $\mathrm{wt} \mathrm{ml}^{-1}$ in $2 \mathrm{ml}$ final volume, and stored in the dark at $6{ }^{\circ} \mathrm{C}$. In the assay, the bacterial suspensions were incubated at $25{ }^{\circ} \mathrm{C}$ for $3 \mathrm{~min}$. Glucose $(40 \%, \mathrm{w} / \mathrm{v} ; 0.04 \mathrm{ml})$ was added and incubation continued for a further $2 \mathrm{~min}$. The assay was initiated by adding bacteria $(0.2 \mathrm{ml})$ to ${ }^{14} \mathrm{C}$-labelled amino-acid solution $(0.2 \mathrm{ml})$ which had been equilibrated at $25^{\circ} \mathrm{C}$. After $30 \mathrm{~s}$, a single $0.2 \mathrm{ml}$ sample was taken, filtered through an Oxoid bacterial filter $(25 \mathrm{~mm}, 0.4 \mu \mathrm{m}$ pore size), and washed with $5 \mathrm{ml}$ chloramphenicol medium (at room temperature, 20 to $24{ }^{\circ} \mathrm{C}$ ). In control assays, bacteria treated with toluene ( $\%$, v/v) for 5 min accumulated less than I \% of the radioactivity of untreated bacteria. Results have not been corrected for control values.

Preparation of bacterial extracts. Frozen bacteria were thawed, resuspended in $5 \mathrm{ml}$ Tris buffer $\mathrm{pH} 8 \cdot 0$, and sonicated $(4 \times 30 \mathrm{~s})$ using a Dawe Soniprobe, set at 4 . Cell debris was sedimented by centrifuging at $30000 \mathrm{~g}$ for $30 \mathrm{~min}$, and the supernatant was used as the source of the enzymes. In the derepression experiments, whole cells were assayed for glutamine synthetase. Frozen bacteria were thawed, resuspended in $3 \mathrm{ml}$ Tris buffer $\mathrm{pH} \mathrm{8.0,}$ and sufficient bacteria were removed to make up $3 \mathrm{ml}$ with at least $\mathrm{I} \mathrm{mg}$ dry $\mathrm{wt}^{\mathrm{m}} \mathrm{l}^{-1}$. Toluene $(\mathrm{I} \%, \mathrm{v} / \mathrm{v})$ was added to this bacterial suspension, and the mixture was shaken vigorously for $30 \mathrm{~min}$ at $37^{\circ} \mathrm{C}$.

Enzyme assays. Glutamine synthetase (EC. 6.3.I.2) was assayed using the $\gamma$-glutamyl transfer reaction (Stadtman et al., I970). Blanks, without ADP and arsenate, were included for every assay condition and the results were subtracted from those obtained with the complete reaction mixture. In this assay, the activity measured in the presence of $\mathrm{Mn}^{2+}$ represented total glutamine synthetase activity (adenylylated and unadenylylated). The addition of $\mathrm{Mg}^{2+}(60 \mathrm{mM})$ inhibited the activity of the adenylylated enzyme, so that only the biosynthetically active, unadenylylated units were measured.

Glutamate dehydrogenase (EC. I.4.r.4) and glutamate synthase (EC. 2.6.1.53) were assayed spectrophotometrically by following the disappearance of NADPH, as described by Cole et al. (1974). Results for blanks, without ammonium chloride (for the glutamate dehydrogenase assay) or glutamine (for glutamate synthase), were subtracted from those 
Table 2. Effect of nitrogen availability on glutamine transport in a wild-type strain and a transport-defective mutant

The bacteria were grown overnight in $0.1 \%$ Casamino acids and $40 \mathrm{~mm}-\left(\mathrm{NH}_{4}\right)_{2} \mathrm{SO}_{4}$. They were subcultured $1 / 200$ into limiting- or excess-nitrogen media and grown until late-exponential phase. Transport [nmol $\left.\min ^{-1}(\mathrm{mg} \text { dry wt })^{-1}\right]$ was determined as described in Methods.

\begin{tabular}{|c|c|c|c|c|c|}
\hline \multirow[b]{2}{*}{ Expt } & \multirow[b]{2}{*}{ Genotype } & \multicolumn{2}{|c|}{ Nitrogen source } & \multicolumn{2}{|c|}{ Transport of glutamine } \\
\hline & & Cas* & $\mathrm{NH}_{4} \dagger$ & $\mathrm{I} \mu \mathrm{M}$ & $.20 \mu \mathrm{M}$ \\
\hline I $a$ & $\operatorname{gln} P^{+}$ & + & - & 4.55 & $7 \cdot 73$ \\
\hline I $b$ & $g \ln P^{+}$ & + & + & $2 \cdot 67$ & $5 \cdot 59$ \\
\hline $2 a$ & $g \ln P 252$ & + & - & 0.14 & $3 \cdot 67$ \\
\hline $2 b$ & $g \ln P 252$ & + & + & 0.07 & 4.04 \\
\hline
\end{tabular}

obtained with the complete reaction mixture. The blank values for glutamate synthase were obtained in separate determinations from those yielding total activity.

All enzyme levels are reported as specific activities and are the averages of duplicate determinations done on at least two independent cultures. The ranges of activities found with the control culture ( $g$ alE) grown in limiting-nitrogen medium were: glutamine transport, $7 \cdot 13$ to $9 \cdot 22 \mathrm{nmol} \mathrm{min}{ }^{-1}$ (mg dry wt) ${ }^{-1}$; unadenylylated glutamine synthetase, 203 to 806; glutamate dehydrogenase, 120 to I7I; and glutamate synthase, 30 to $45 \mathrm{nmol} \mathrm{min}^{-1}$ (mg protein) $)^{-1}$.

Protein concentrations were determined by the Folin method (Lowry et al., I95I) using bovine serum albumin (Sigma) as standard.

\section{RESULTS}

\section{Effect of nitrogen availability on glutamine transport}

There are two different glutamine transport systems in S. typhimurium. The high-affinity system has a $K_{\mathrm{m}}$ of $0.2 \mu \mathrm{M}$ and a $V_{\max }$ of $2 \mathrm{nmol} \mathrm{min}^{-1}(\mathrm{mg} \text { dry wt) })^{-1}$, and the low-affinity system has a $K_{\mathrm{m}}$ of Io $\mu \mathrm{M}$ and a $V_{\max }$ of $3.5 \mathrm{nmol} \mathrm{min}^{-1}$ (mg dry wt) ${ }^{-1}$ (Ayling \& Betteridge, I975; and unpublished results). It was possible that these would be affected differently by nitrogen availability. Because the affinities of these two systems differed 5o-fold, appropriate concentrations of glutamine were selected to allow the relative contributions of the two systems to be assessed. With I $\mu$ M-glutamine, essentially only the high-affinity system was assayed (the velocity of the low-affinity system was only 10 \% of $V_{\max }$ ); whereas at $20 \mu \mathrm{M}$, both high- and low-affinity systems were measured (the velocities of the high- and lowaffinity systems were $100 \%$ and $66 \%$ of $V_{\max }$ respectively).

Table 2 shows the effect on glutamine transport of growth in either limiting-nitrogen medium ( $0.1 \%$ Casamino acids) or in excess-nitrogen medium ( $0.1 \%$ Casamino acids and $40 \mathrm{~mm}$-ammonium sulphate). Growth of the wild-type strain $\left(\mathrm{gln} \mathrm{P}^{+}\right)$in limiting-nitrogen conditions (expt. I $a$ ) resulted in a $70 \%$ increase in high-affinity transport compared with the same strain grown in excess nitrogen (expt. I $b$ ). When assayed with $20 \mu \mathrm{M}$-glutamine, transport was higher in bacteria grown in limiting-nitrogen media than in those grown with excess nitrogen. However, if the activity at I $\mu \mathrm{M}$ is subtracted from that at $20 \mu \mathrm{M}$, it is seen that low-affinity transport is not affected by growth in limiting-nitrogen media [values are 3.2 and $2.9 \mathrm{nmol} \mathrm{m^{-1 }}(\mathrm{mg} \text { dry wt) })^{-1}$ respectively in expts $\mathrm{I} a$ and $\left.\mathrm{I} b\right]$.

When a glutamine transport-defective mutant $(g \ln P 252)$, which is defective for the high- 


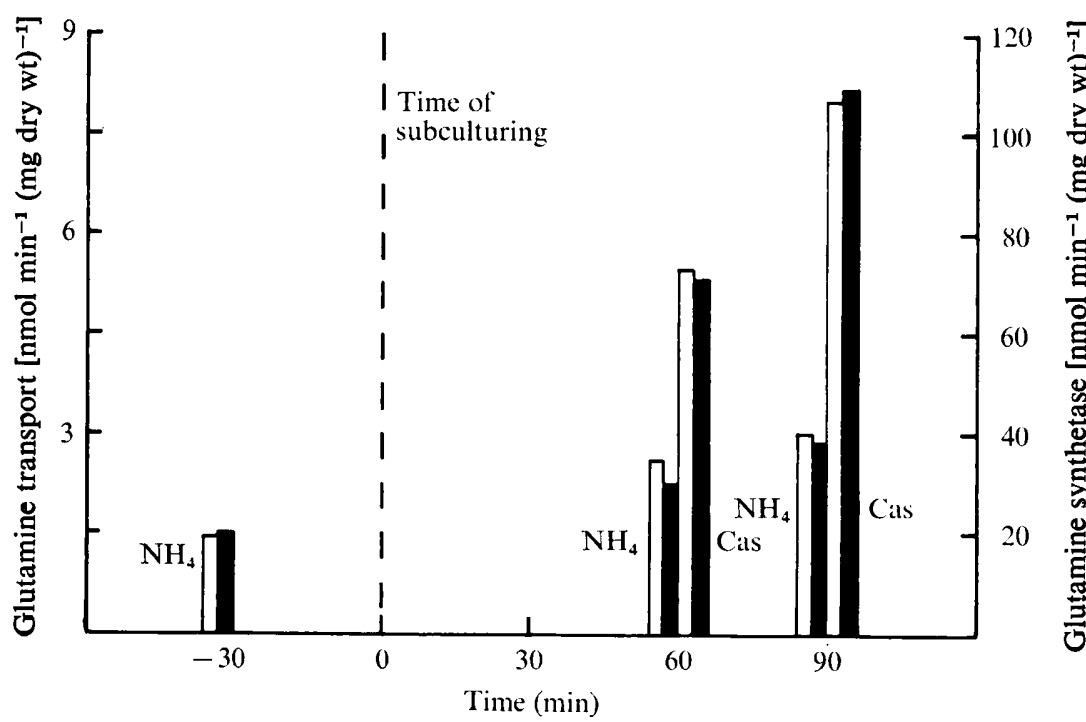

Fig. I. Derepression of glutamine transport and glutamine synthetase activities in the wild-type strain. Bacteria, strain HUI90, were grown overnight in medium containing $40 \mathrm{mM}-\left(\mathrm{NH}_{4}\right)_{2} \mathrm{SO}_{4}$, subcultured into the same medium and grown for $75 \mathrm{~min}$ to exponential phase. This culture was harvested $(-30 \mathrm{~min})$ and portions used for transport and glutamine synthetase assays as well as subculturing (at $\mathrm{o}$ min) into limiting (Cas) or excess-nitrogen $\left(\mathrm{NH}_{4}\right)$ media. The bars represent activities of glutamine transport assayed with I $\mu \mathrm{M}$-glutamine (open bars), and unadenylylated (active) glutamine synthetase (solid bars). Assays were performed as described in Methods.

affinity transport system, was assayed with I $\mu$ M-glutamine, transport was only $3 \%$ of wild-type control levels (expts $2 a$ and $2 b$ ). There was no difference between cultures grown in limiting- or excess-nitrogen media when assayed with $20 \mu \mathrm{M}$-glutamine. This confirms that only the high-affinity transport system is regulated by nitrogen availability, and only this system was assayed in the following experiments.

\section{Derepression of glutamine transport and glutamine synthetase activities in a wild-type strain}

Woolfolk, Shapiro \& Stadtman (I966) have shown that, in E. coli, glutamine synthetase is repressed by growth in excess ammonia. The results in the previous section indicated that, in $S$. typhimurium, the high-affinity glutamine transport system was also repressed by ammonia. Figure I shows the derepression of glutamine transport and active (unadenylylated) synthetase when bacteria were transferred from conditions of excess ( $0.03 \%$ Casamino acids and $40 \mathrm{~mm}$-ammonium sulphate) to limiting nitrogen $(0.03 \%$ Casamino acids). Transport and synthetase activities both increased at the same rate. After subculturing for $60 \mathrm{~min}$, both glutamine transport and active glutamine synthetase had increased three- to fourfold, compared with the original ammonium-grown culture. After $90 \mathrm{~min}$, transport and synthetase activity had increased five- to sixfold compared with the original inoculum.

When subcultured from excess-nitrogen medium into the same medium, the increase in activities was much less. By 90 min, these activities had increased about twofold compared with the levels in the initial inoculum. The results indicate that subculturing from excessnitrogen to nitrogen-limited conditions resulted in a simultaneous derepression of both glutamine transport and glutamine synthetase which lasted for at least $90 \mathrm{~min}$. 


\section{Table 3. Effect of pretreatment with glutamine on glutamine transport in the wild-type strain}

Bacteria, strain HUI90, were grown overnight with or without L-glutamine $\left(2 \mathrm{mg} \mathrm{ml}^{-1}\right)$, harvested, subcultured I/200 into media as described in Methods, and grown until late-exponential phase. The culture grown without glutamine was divided: and glutamine (to give $2 \mathrm{mg} \mathrm{ml}^{-1}$ ) was added to one half. All cultures were immediately harvested for assaying. Transport [nmol min ${ }^{-1}$ (mg dry wt $)^{-1}$ ] was determined as described in Methods.

\begin{tabular}{|c|c|c|c|c|}
\hline \multirow[b]{2}{*}{ Expt } & \multicolumn{2}{|c|}{ Nitrogen source } & \multirow{2}{*}{$\begin{array}{l}\text { Addition of Gln† } \\
\text { during harvesting }\end{array}$} & \multirow{2}{*}{$\begin{array}{l}\text { Transport of } \\
\text { I } \mu \mathrm{M} \text {-glutamine }\end{array}$} \\
\hline & Cas* & Gln $\dagger$ & & \\
\hline $\mathbf{I}$ & + & + & - & $I \cdot 64$ \\
\hline $2 a$ & + & - & + & $6 \cdot 57$ \\
\hline $2 b$ & + & - & - & $6 \cdot 47$ \\
\hline
\end{tabular}

\section{Effect of pretreatment with glutamine on glutamine transport}

Table 3 shows the repression of glutamine transport found when bacteria were grown in L-glutamine $\left(2 \mathrm{mg} \mathrm{ml}^{-1}\right)$; glutamine transport was only $25 \%$ of that in a control culture grown without.glutamine. Addition of glutamine to the control culture during harvesting did not reduce transport activity. This suggests that the glutamine pool does not regulate high-affinity glutamine transport by feedback inhibition, although it is possible that the glutamine is metabolized before the bacteria can be assayed for transport activity.

\section{Effect of nitrogen availability on the enzymes of glutamate and glutamine metabolism, and glutamine transport in a wild-type strain and a glutamine auxotroph}

Table 4 shows the effect of growth in conditions of either limiting nitrogen $(0.1 \%$ Casamino acids) or excess nitrogen ( $0.1 \%$ Casamino acids and $40 \mathrm{~mm}$-ammonium sulphate). Experiment I $a$ demonstrates the effect of growing the wild-type strain in limiting nitrogen. In comparison with expt. I $b$ (excess nitrogen), the activity of unadenylylated glutamine synthetase was I6-fold higher and glutamine transport was about twofold higher. The levels of glutamate dehydrogenase and glutamate synthase activities on the other hand, were not markedly altered, confirming the findings of Miller \& Stadtman (1972) who showed that in $E$. coli the ammonium ion concentration did not regulate the levels of these two enzymes.

In expts $2 a$ and $2 b$, the effects of adding glutamine $\left(2 \mathrm{mg} \mathrm{ml}^{-1}\right)$ to cultures grown in either limiting- or excess-nitrogen medium are shown. In expt. $2 a$, the addition of glutamine to limiting-nitrogen medium resulted in reductions of glutamine transport to $34 \%$, and glutamine synthetase activity to $4 \mathrm{I} \%$ of the control levels (expt. I $a$ ). Glutamate dehydrogenase and glutamate synthase activities were not altered markedly. Growth with both excess nitrogen and glutamine (expt. $2 b$ ) did not affect glutamine synthetase, glutamate dehydrogenase and glutamate synthase activities; but resulted in a lower level of transport activity than with either treatment individually, giving only $49 \%$ of the control levels (expt. I $b$ ).

In expts $3 a$ and $3 b$, enzyme activities in the $g \ln$-Io glutamine auxotroph (Table I) were examined. Glutamine synthetase activity was lacking whether the strain was grown with or without ammonia, and the levels of glutamate dehydrogenase and glutamate synthase were reduced. However, glutamine transport activity was nearly three times higher than in 


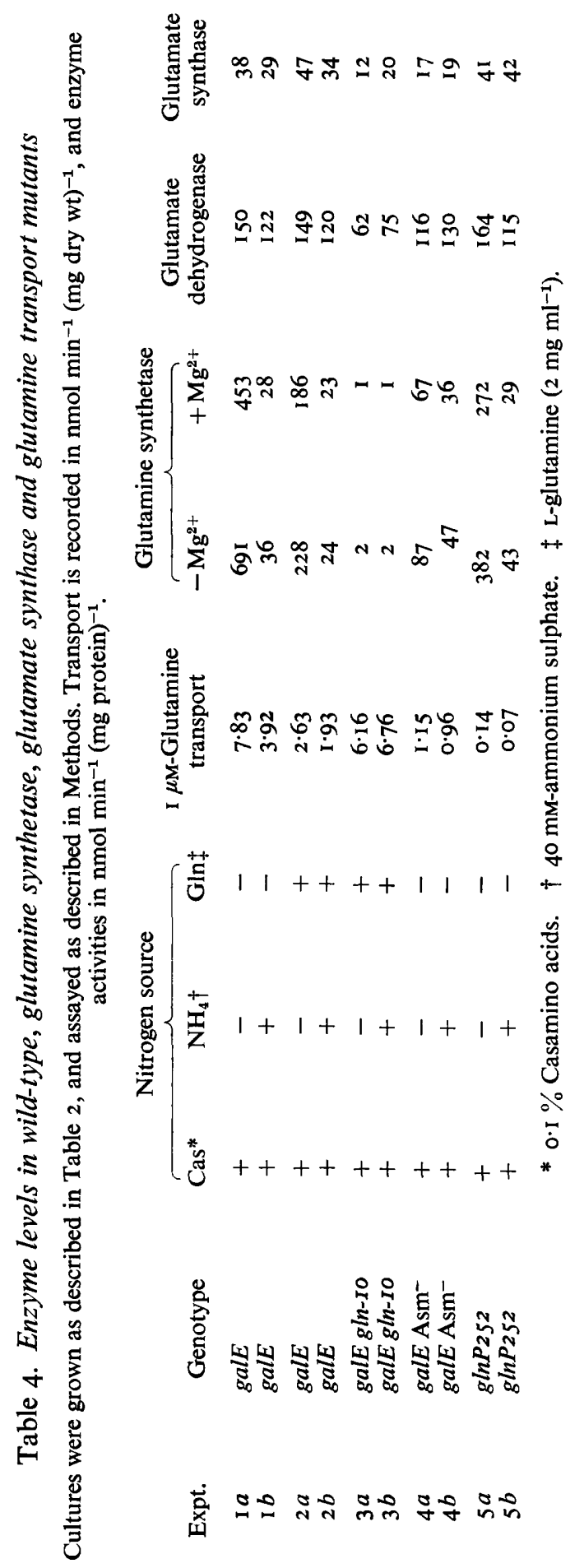


the wild-type strain (expt. $2 a$ ), and this high activity was not reduced by growth in ammonia (expt. $3 b$ ). A transductant to glutamine-independence has normal regulation of glutamine transport (Betteridge, unpublished results), suggesting that the glutamine synthetase defect and the effect on glutamine transport result from the same mutation. Brenchley, Baker \& Patil (1975) suggest that the reduced activities of glutamate dehydrogenase and glutamate synthase in $g \ln$-IO might be the effect of a second mutation; they describe other glutamine auxotrophs which do not have lowered activities for these enzymes. A glutamine auxotroph hisF $\Delta 645 \operatorname{gln}-52$ is known to have normal activity for glutamate dehydrogenase (Kustu \& McKereghan, 1975) and we have shown that it has normal activity for glutamate synthase $\left(60 \mathrm{nmol} \mathrm{min}{ }^{-1}\right.$ (mg protein) $\left.{ }^{-1}\right]$. Nevertheless, this mutant has an enhanced glutamine transport activity comparable with that of $g \ln -I O\left[4 \cdot 33 \mathrm{nmol} \mathrm{min}^{-1}\left(\mathrm{mg}\right.\right.$ dry wt) $\left.{ }^{-1}\right]$.

\section{Effect of a glutamate synthase mutation on glutamine transport and the enzymes of glutamate metabolism}

Brenchley et al. (I973) showed that in K. aerogenes a defect in glutamate synthase (asm-) prevented the derepression of glutamine synthetase, and that histidase formation was permanently repressed. Table 4 (expt. 4) shows enzyme activities in an Asm- mutant (Table I) isolated as unable to grow in low-ammonia medium and subsequently found to be resistant to methionine sulphoximine. The activities of glutamate synthase, glutamine synthetase and glutamine transport were all lower than in the wild-type strain in expt. I. The activities of glutamine transport and glutamine synthetase did not increase when this strain was transferred from excess- to limiting-nitrogen media, and glutamate synthase activity remained low as was expected.

Brenchley et al. (1975) have shown that growth of a wild-type strain ( $\mathrm{galE}$ ) in ammonia medium supplemented with Casamino acids $(0.4 \%)$ resulted in lower activities for glutamate synthase, glutamate dehydrogenase and glutamine synthetase than when the same strain was grown in ammonia medium without Casamino acids. We found that the wild-type strain grown in ammonia medium without Casamino acids had high activities for glutamate synthase and glutamate dehydrogenase $\left[105\right.$ and $442 \mathrm{nmol} \mathrm{min}^{-1}$ (mg protein) ${ }^{-1}$ respectively]. However, when the $\mathrm{Asm}^{-}$mutant was grown in ammonia medium without Casamino acids, the activity of glutamate synthase did not increase, whereas glutamate

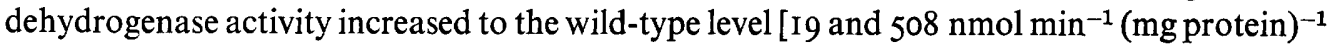
respectively]. These results were obtained on single cultures.

The low level of transport activity in the Asm- mutant suggested that $g \ln P$ mutants might be an extreme class of $\mathrm{Asm}^{-}$mutants that are severely affected for glutamine transport, especially as the $g \ln P$ mutants were isolated as resistant to methionine sulphoximine (Betteridge \& Ayling, 1975). When examined, $g \ln P 252$ had normal regulation and activities of glutamine synthetase (Table 4, expt. 5) and had high activity for glutamate synthase when grown in ammonia medium without Casamino acids $\left[203 \mathrm{nmol} \mathrm{min}{ }^{-1}\right.$ (mg protein $)^{-1}$.

\section{DISCUSSION}

Our results show that in $S$. typhimurium the high-affinity glutamine transport system responds to the nitrogen availability of the medium in the same way as does glutamine synthetase. Willis, Iwata \& Furlong (1975) have described a similar effect in E. coli. The derepression experiments (Fig. I) showed that glutamine transport and glutamine synthetase activities increased at the same rate when the wild-type strain was transferred from excess- 
nitrogen medium (containing ammonia) to limiting-nitrogen medium (without ammonia) These increases, however, were not coordinate, because after prolonged growth in limitingnitrogen conditions (Table 4), glutamine synthetase activity increased to a greater extent than glutamine transport activity (I6-fold compared to twofold). Although these results indicate that both glutamine transport and glutamine synthetase are repressed by growth in ammonia-containing media, they do not indicate whether transport and synthetase activities are regulated by the same mechanism, nor whether it is ammonium ions or some product of their metabolism that is responsible for the repression.

When a glutamine auxotroph (that lacks biosynthetically active glutamine synthetase) was examined, it had a permanently high level of glutamine transport which was not reduced by growth in ammonia-containing medium. This showed that in addition to ammonia, glutamine synthetase is in some way involved in the regulation of glutamine transport. In $K$. aerogenes, glutamine synthetase has been implicated as the regulator of some of the enzymes responsible for the synthesis of glutamate. Prival et al. (1973) found that mutants mapping in the structural gene for glutamine synthetase $(g \ln A)$ had high glutamate dehydrogenase activity and low histidase activity. Other mutants $\left(\mathrm{Gln}^{-}\right)$, that have since been shown to map in the same gene (DeLeo \& Magasanik, 1975), have low glutamate dehydrogenase and high histidase activities. Tyler, DeLeo \& Magasanik (1974) confirmed a regulatory role for glutamine synthetase when they demonstrated that purified unadenylylated glutamine synthetase (from a histidase-constitutive mutant of $K$.aerogenes) could activate the transcription of the histidine-utilizing operon of Salmonella in vitro. Recently, Foor, Janssen \& Magasanik (1975) have shown that in $K$. aerogenes adenylylated glutamine synthetase inhibits the transcription of the structural gene $(g \ln A)$ for glutamine synthetase. An Asm- mutant had low glutamate synthase and glutamine synthetase activites, confirming the results of Steimer-Veale \& Brenchley (1974). This mutant has permanently low glutamine transport activity. Brenchley et al. (I973) have shown that an asm- mutant of $K$. aerogenes had permanently low glutamine synthetase and histidase activities. They believed that the effect on histidase was mediated via glutamine synthetase.

One hypothesis consistent with the present results is that the glutamine synthetase protein is directly involved in the regulation of the glutamine transport system. Two mechanisms of control are possible with this hypothesis, with glutamine synthetase acting either as a negative repressor or as a positive activator. According to the repressor model, both glutamine synthetase (in its adenylylated form) and ammonia (or a product of its metabolism) would be necessary for regulation. The gln-Io glutamine auxotroph should have glutamine synthetase which is unable to function in either biosynthesis or regulation. The effect of the Asm- mutation is difficult to explain on this model; the low level of glutamate synthase activity should result in high transport activity.

Alternatively, unadenylylated glutamine synthetase could function as an activator in the synthesis of the glutamine transport system (as with the histidase of $K$. aerogenes). However, this model requires that the glutamine auxotroph produces constitutively a glutamine synthetase protein inactive in biosynthesis but still active in regulation. [Attempts to determine whether $g \ln$ - $I O$ is of the $\mathrm{GlnC}^{-}$phenotype have failed (Betteridge, unpublished results).] Whilst mutants of this type have been isolated in Klebsiella (DeLeo \& Magasanik, 1975), they are rare. On this model, the mutation in the Asm- mutant would cause low transport activity by preventing the derepression of glutamine synthetase.

Some of the enzymes that are regulated by glutamine synthetase in $K$. aerogenes are not regulated in the same way in Salmonella. Prival \& Magasanik (197I) showed that histidase activity in Salmonella did not increase in a nitrogen-limited culture. The results of 
Brenchley et al. (1975) and those in Table 4 (expt. 3) showed that glutamate dehydrogenase was not regulated by ammonia availability and its activity was not altered in glutamine synthetase mutants.

Other explanations of the results are possible. Although direct measurements of the glutamine pool have not been made, our results suggest that the glutamine pool does not directly control glutamine transport. In $E$. coli, Willis et al. (I975) found that there was no correlation between the activities of glutamine synthetase and glutaminases A and B, suggesting that the enhanced activity of the glutamine transport system is not the result of depletion of the glutamine pool. Prusiner (I975) has shown that glutaminase A activity is low in nitrogen-limited cultures. Although the present work has demonstrated a strong correlation between glutamine transport and glutamine synthetase, further work will be necessary to determine the mechanism of this effect.

We thank Dr J. E. Brenchley for providing strains and unpublished information, Dr J. A. Cole for showing P.R.B. the glutamine synthetase assay, Dr S. G. Kustu for strains, and Dr Cole and Miss B. M. Kavanagh for helpful discussion of the manuscript. P.R.B. was supported by an S.R.C. studentship.

\section{REFERENCES}

Ayling, P. D. \& BetTeridge, P. R. (1975). Transport of methionine and glutamine in mutants of Salmonella typhimurium. Heredity 35, 436-437.

Betteridge, P. R. \& Ayling, P. D. (I975). The role of methionine transport-defective mutations in resistance to methionine sulphoximine in Salmonella typhimurium. Molecular and General Genetics $\mathbf{r 3}^{8}, 41-52$.

Betteridge, P. R. \& Ayling, P. D. (1976). The regulation of glutamine transport in wild-type and mutant strains of Salmonella typhimurium. Heredity 36, 29I-292.

Brenchley, J. E., Baker, C. A. \& Patil, L. G. (I975). Regulation of the ammonia assimilatory enzymes in Salmonella typhimurium. Journal of Bacteriology 124, 182-I 89.

Brenchley, J. E., Prival, M. J. \& Magasanik, B. (I973). Regulation of the synthesis of enzymes responsible for glutamate formation in Klebsiella aerogenes. Journal of Biological Chemistry 248, 61 22-61 28.

Cole, J. A., Coleman, K. J., Compton, B. E., Kavanagh, B. M. \& Keevil, C. W. (1974). Nitrite and ammonia assimilation by anaerobic continuous cultures of Escherichia coli. Journal of General Microbiology 85, I I-22.

DeLeo, A. B. \& MagasantK, B. (1975). Identification of the structural gene for glutamine synthetase in Klebsiella aerogenes. Journal of Bacteriology 121, 313-319.

Foor, F., JANSSEN, K. A. \& MAGASANIK, B. (1975). Regulation of synthesis of glutamine synthetase by adenylylated glutamine synthetase. Proceedings of the National Academy of Sciences of the United States of America 72, 4844-4848.

Kustu, S. G. \& MCKereghan, K. (I975). Mutations affecting glutamine synthetase activity in Salmonella typhimurium. Journal of Bacteriology 122, 1006-1016.

Lowry, O. H., Rosebrough, N. J., FarR, A. L. \& Randall, R. J. (I95I). Protein measurement with the Folin phenol reagent. Journal of Biological Chemistry 193, 265-275.

Meister, A. (1962). Amide nitrogen (survey). In The Enzymes, vol. 6, pp. 247-266. Edited by P. D. Boyer H. Lardy and K. Myrback. New York: Academic Press.

Miller, R. E. \& Stadtman, E. R. (1972). Glutamate synthase from Escherichia coli. Journal of Biological Chemistry 247, 7407-7419.

Prival, M. J., Brenchley, J. E. \& Magasanik, B. (1973). Glutamine synthetase and the regulation of histidase formation in Klebsiella aerogenes. Journal of Biological Chemistry 248, 4334-4344.

Prival, M. J. \& Magasanik, B. (I97I). Resistance to catabolite repression of histidase and proline oxidase during nitrogen-limited growth of Klebsiella aerogenes. Journal of Biological Chemistry 246, 6288-6296.

Prusiner, S. (1975). Regulation of glutaminase levels in Escherichia coli. Journal of Bacteriology 123, 992-999.

SENIOR, P. J. (1975). Regulation of nitrogen metabolism in Escherichia coli and Klebsiella aerogenes: studies with the continuous-culture technique. Journal of Bacteriology 123, 407-418.

Stadtman, E. R. \& Ginsburg, A. (1974). The glutamine synthetase of Escherichia coli: structure and control. In The Enzymes, vol. 10, pp. 755-807. Edited by P. D. Boyer. New York: Academic Press. 
Stadtman, E. R., Ginsburg, A., Ciardi, J. E., Yeh, J., Hennig, S. B. \& Shapiro, B. M. (1970). Multiple molecular forms of glutamine synthetase produced by enzyme catalyzed adenylylation and deadenylylation reactions. Advances in Enzyme Regulation 8, 99-1 18.

Steimer-Veale, K. \& BRenChley, J. E. (1974). Characterization of Salmonella typhimurium strains sensitive and resistant to methionine sulfoximine. Journal of Bacteriology II9, 848-856.

Tempest, D. W., MeErs, J. L. \& Brown, C. M. (I973). Glutamate synthetase (GOGAT); a key enzyme in the assimilation of ammonia by prokaryotic organisms. In The Enzymes of Glutamine Metabolism, pp. 167182. Edited by S. Prusiner and E. R. Stadtman. New York: Academic Press.

Tyler, B., Deleo, A. B. \& Magasanik, B. (1974). Activation of transcription of hut DNA by glutamine synthetase. Proceedings of the National Academy of Sciences of the United States of America 7r, 225-229.

Willis, R. C., IwATA, K. K. \& FuRlong, C. E. (1975). Regulation of glutamine transport in Escherichia coli. Journal of Bacteriology 122, $1032-1037$.

Woolfolk, C. A., Shapiro, B. \& STadtman, E. R. (I966). Regulation of glutamine synthetase. I. Purification and properties of glutamine synthetase from Escherichia coli. Archives of Biochemistry and Biophysics 116, 177-192. 